\title{
LORANTHACEAE (MISTLETOE), A PHYTOPARASITIC DISPERSED BY BIRDS ON ANNUITY CROPS IN PERIURBAN AREAS OF THE DALOA DEPARTMENT, IN CENTRAL WEST CÔTE D'IVOIRE
}

\author{
AMON Anoh Denis-Esdras ${ }^{1 *}$, MRANKPA Agnero Stephane1, KOUASSI Kouadio Henri ${ }^{1}$ and SORO Kafana ${ }^{2}$ \\ ${ }^{1}$ Université Jean Lorougnon Guedé, UFR Agroforesterie. BP 150 Daloa, Côte d'Ivoire \\ ${ }^{2}$ Centre de Recherche en Ecologie, Université NANGUI Abrogoua (CRE/UNA),08 BP 108 Abidjan 08, Côte \\ d'Ivoire
}

\author{
https://doi.org/10.35410/IJAEB.2020.5525
}

\begin{abstract}
In Côte d'Ivoire, Loranthaceae invades numerous wild and cultivated woody species that they infest. The objective of this study is to show the major role of birds in the dispersion of phytoparasites on crops.

The botanical inventory identified five (5) species of Loranthaceae on annuity crops in periurban areas of the Daloa department. Among the species inventoried, Tapinanthus bangwensis is very infesting on cocoa trees and coffee trees, and Phragmanthera capitata more abundant on rubber trees. Cocoa trees are much infested with an average rate of $52.09 \%$.

Observations on the behavior of visiting birds in the clumps of Loranthaceae confirmed the role of 13 bird species distributed in seven (7) genera and seven (7) families (Nectariniidae (3), Psittacidae (1), Capitonidae (5), sylviidae (1), Colombidae (1), Pycnonotidae (1) and Rhipiduridae (1)). Among these species, two (2) of the family Nectariniidae are very active in their clusters of flowers: Nectarinia senegalensis and N. pulchella and three (3) species of Capitonidae have a more active role in the consumption of berries and in the dissemination seeds. They are: Pogoniulus atroflavus, P. chrysonocus and P. scolopaceus. These results obtained on the responsibility of birds in the dispersion of Loranthaceae on crops suggest upstream lines of struggle that must be taken into account in the defense of crops.
\end{abstract}

Keywords: Annuity crops, Loranthaceae, bird species, dispersal, crop defence.

\section{INTRODUCTION}

Loranthaceae (guis) are hemiparasitic vascular plants that live at the expense of other spontaneous and cultivated woody host species (Traoré et al., 2003). In West Africa, particularly in Côte d'Ivoire, in the countryside, these phytoparasites invade an abundance of trees and shrubs. In addition, within a host population, some woody plants are often parasitized much more than others (Amon, 2014). Indeed, these phytoparasites without being specific to hosts have found in certain crops such as cocoa trees, coffee trees, rubber trees, citrus fruits (orange, lemon, grapefruit, mandarin), cola trees, guavas and avocados prosperous subjects, they negatively affect their growth and yield (Soro 1999; Boussim, 2002; Salle 2004; Soro, 2010). 
Vol. 5, No. 04; 2020

ISSN: $2456-8643$

Although several factors act their parasitism on woody plants, some studies have shown that the mechanisms of dispersal of these hemiparasites plants are vested in birds that disseminate their seeds (Dembélé et al., 1994; Boussim, 2002).

But, how do you explain this link between birds and parasitic vascular plants of the family Loranthaceae that proliferate from trees to trees of crops if we do not have information on the avian species involved? What are the plant populations dispersed by birds on the annuity crops of village plantations in periurban areas of Daloa, in central west Côte d'Ivoire? In Côte d'Ivoire, various studies have been carried out on the Loranthaceae (Balle and Halle, 1961; Traoré et al., 2003, Soro, 2006; Soro, 2010), however, these studies have been oriented more toward evaluation, infestation of their attacks on host woody plants.

However, the involvement of birds in the expansion of plant pests, particularly on cash crops, although real (Dembélé et al., 1994; Overton, 1994; Amon, 2014), remains very little studied and documented in Côte d'Ivoire.

However, the fight to be carried out in cultures against these hemiparasites requires to know the agents of their dispersion on the feet of the host subjects. The present study is concerned with the species of Loranthaceae that live at the expense of the host plants of cash crops, their degree of attack and the behavior of birds visiting these clumps in order to undertake control actions.

\section{MATERIALS AND METHODS}

\subsection{Study site}

The study was carried out in village plantations of annuity crops in periurban areas of the department of Daloa (Figure 1) located between $6^{\circ} 27^{\prime} 00^{\prime \prime}$ north latitude and $5^{\circ} 56^{\prime} 00^{\prime \prime}$ west longitude, in in central west Côte d'Ivoire, $383 \mathrm{~km}$ from Abidjan. The climate of the department of Daloa is of equatorial type of transition with 2 seasons of rain which alternate with two dry seasons (Eldin, 1971). The annual rainfall varies between 1300 and $1800 \mathrm{~mm}$. The average annual temperature is $27.0{ }^{\circ} \mathrm{C}$. The vegetation belongs to the mesophilic sector of the Guinean domain (Guillaumet and Adjanohoun, 1971). It consists of mosaics of Guinean forests and savannahs.

\subsection{Material}

The material consists of biological material composed of specimens of Loranthaceae and individuals of cultures. Technical equipment consisting of a survey sheet, a tape measure, a geographic positioning device (GPS), a pair of binoculars, a digital camera and pruning shears. 
Vol. 5, No. 04; 2020

ISSN: $2456-8643$

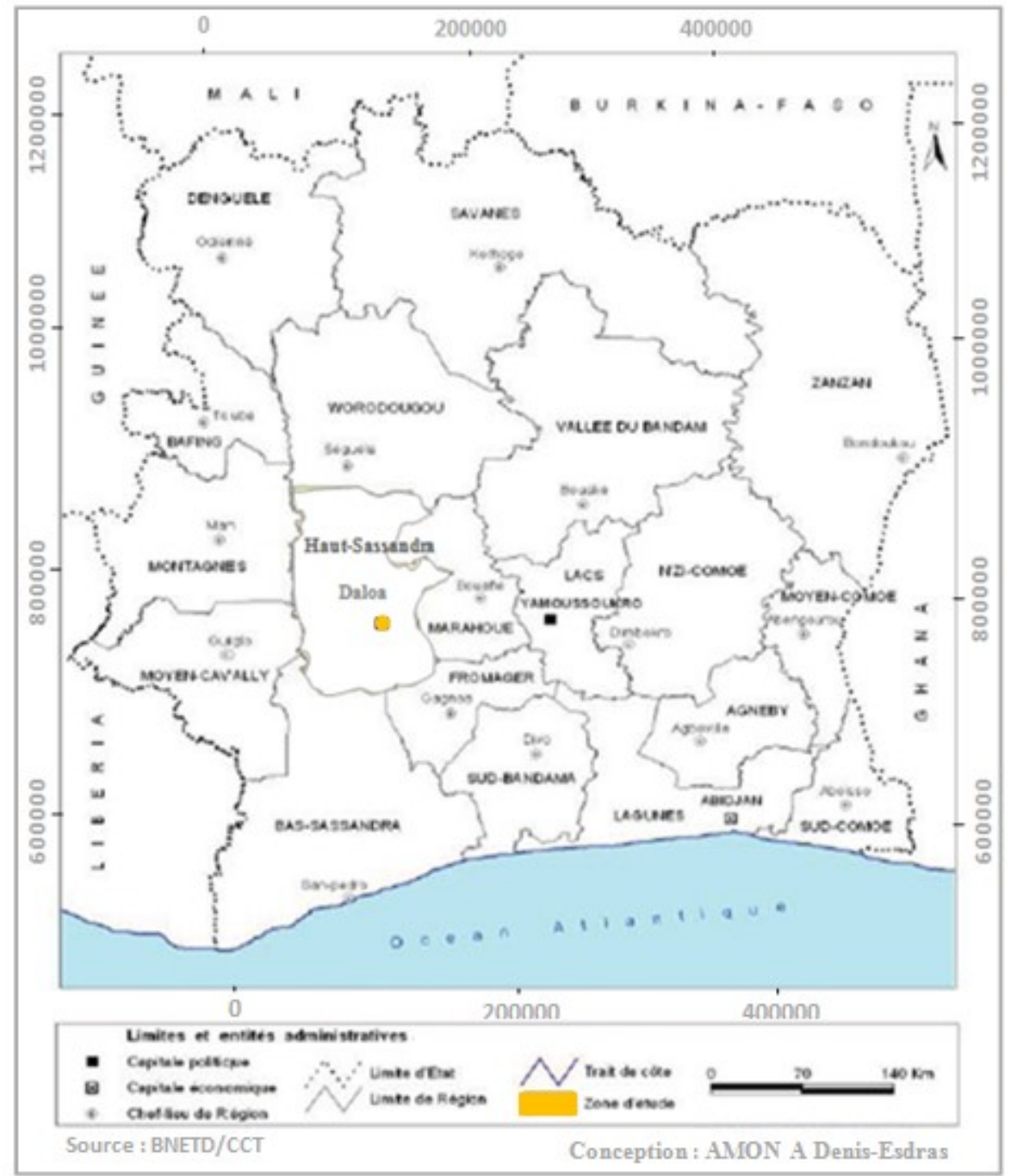

Figure 1: Location of Daloa department, study area

\subsection{Methods}

Field investigations took place in 15 cocoa, coffee and rubber plantations in the periurban areas of Daloa, in west-central Côte d'Ivoire. The criteria for choosing these plantations were their area $(\geq 2.5 \mathrm{ha})$ and their accessibility.

To identify parasitic Loranthaceae species dispersed on crops and the categories of birds involved in their dispersal, two complementary data collection techniques were used. These are surface surveys and direct observations. The surface surveys consisted in delimiting in the plantations single plots of a maximum dimension of one hectare $(100 \mathrm{~m} \times 100 \mathrm{~m})$ each subdivided into strips of $10 \mathrm{~m}$. In each unit plot, the number of tufts of Loranthaceae, the total number of parasitized and non-parasitized crop feet were counted and the name of each parasite species encountered was noted. The data collected made it possible to calculate (Amon, 2006): 
- Infestation rate : $\quad$ Txi $=\frac{\text { Nip }}{\mathrm{Nti}} \times 100$

with (Txi):- Infestation rate; Nip - Number of individuals infected, Nti - Total number of individuals enumerated

- Infestation intensity (Ii):

$$
\mathrm{Ii}=\frac{\mathrm{Nt}}{\mathrm{Nii}}
$$

with Ii - Intensity of infestation; Nt - Total number of tufts of Loranthaceae; Ntii - Total number of infested individuals identified.

Analysis of variance (ANOVA) using STATISTICA version 7.1 software was carried out and a comparison of means by the Newman-Keuls test at the threshold of $\alpha=5 \%$ for cases of significant differences.

For direct observations, they consisted of standing near 30 tufts of Loranthaceae chosen at random from the crop feet in the unit plots and monitoring the behavior of visiting birds using a binocular (Figure 2) in these tufts, and to identify their role. Among these tufts identified, fifteen (15) are in the flowering phase and the fifteen (15) others in the fruiting phase.

These observations were made from 8 a.m. to 12 p.m., twice a week for three months. This method allowed close-up photography and capture of some bird species. These birds observed were divided into two groups according to their behavior within the tufts. They were later identified using appropriate literature (Serle and Morel, 1988; Borrow and Demey, 2008) and documents viewed on the Internet. The observations made were supplemented by information collected from farmers encountered in the plantations studied, often in contact with these bird species.

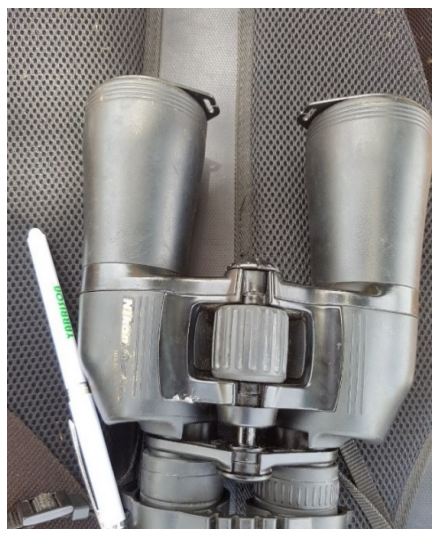

Figure 2: Pair of binoculars to monitor bird behavior in the tufts of Loranthaceae 
Vol. 5, No. 04; 2020

ISSN: $2456-8643$

\section{RESULTS}

\subsection{Phytoparasites scattered by birds on annuity crops}

Five (5) parasitic species of the Loranthaceae family, divided into 3 genera, were inventoried and identified on the annuity crop from the suburban areas of the Daloa department. These are: Globimetula braunii (Engl.) Van Tiegh, Phragmanthera capitata (Spreng.) Ballé (Figure 3), Tapinanthus bangwensis (Engl. And K. Krause) Dancer (Figure 4), T. globiferus (A. Rich.) Tiegh. et T. sessilifolius var. glaber (P. Beauv.) Van Tiegh.

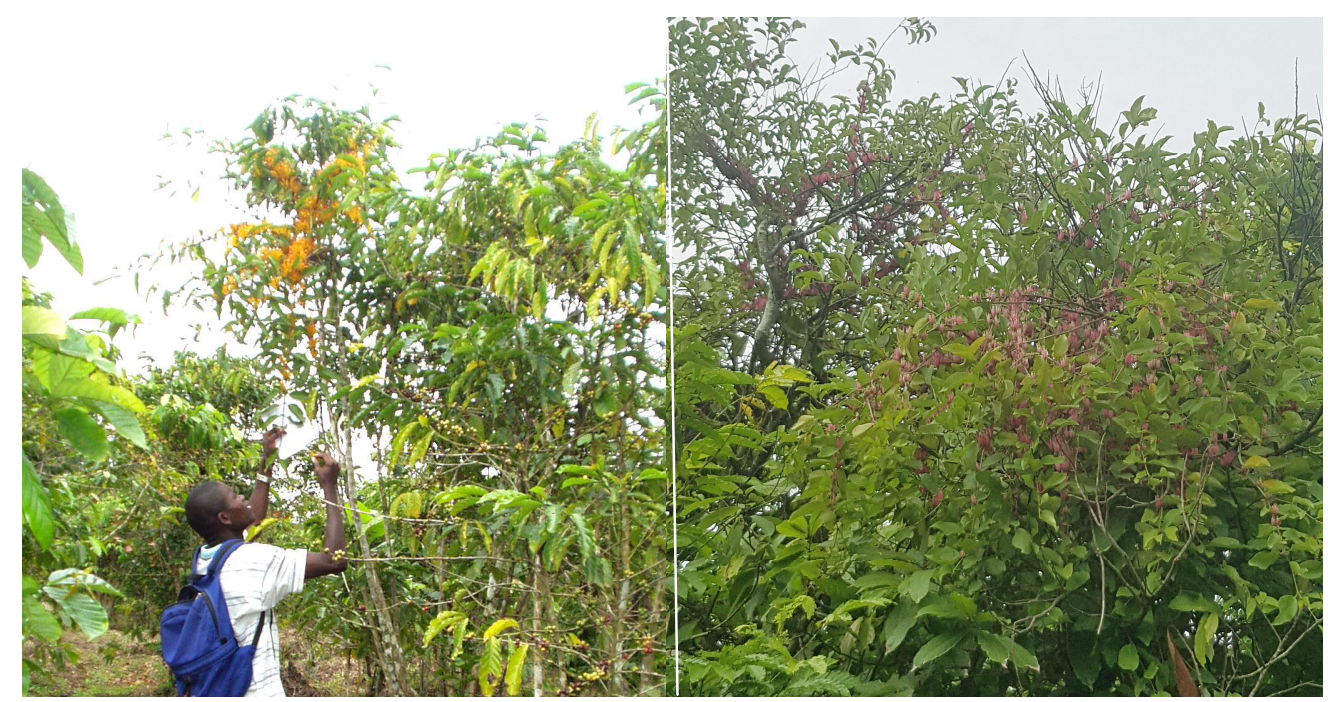

Figure 3: Phragmanthera capitata, parasite

Figure 4: Tapinanthus bangensis, parasite

\subsection{Birds propagating phytoparasites observed and identified}

Four hundred and fifty (450) birds grouped into 13 species, divided into 7 genera and 7 families, visiting the flowering and fruiting shoots of phytoparasitic species have been identified (Table 1). The most diversified family in terms of species is that of Capittonidae with five (5) species, a rate of $71.42 \%$, followed by Nectariniidae (42.85\%). Among these 450 birds, 213 with a tapered and curved nose $(47.33 \%)$ and 237 with a beak, or $52.67 \%$ were observed.

Considering the phenological stages of the tufts visited by birds and the shape of their beaks, two groups of birds are distinguished (Table 1). Group I pollinator birds are less diversified with four (4) species, or 30.76\%. These are Nectarinia senegalensis L., 1766 (Figure5), N. pulchella L., 1766 (Figure6), N. coccinigaster Latham, 1802 of the family of the Nectariniidae and Acanthiza nana Vigors and Horfield, 1827 of the Psittacidae family. They are small, small, very mobile and active birds within clumps of flowers. Among these species, Nectarinia pulchella and $N$. senegalensis with relative frequencies of visits of the respective flowering clumps of the order of $41.80 \%$ and $47.35 \%$ are the most active. The most diversified group II comprises 9 species, or $69.23 \%$. They are Pogoniulus atroflavus Hermann, 1783 or barbion with red rump (Figure 7), $P$. 
Vol. 5, No. 04; 2020

ISSN: $2456-8643$

chrysonocus Temmick, 1832 or little bearded with yellow forehead, P. bilineatus Sundevall, 1850 or barbion with yellow rump, P. pusillus Dumont, 1816 and P. scolopaceus Hermann, 1804 (Figure8), all of the family Capitonidae, Sylvia communis Latham, 1787 or Blackcap (Sylviidae), Streptopelia turtur L., 1758 (Columbidae), Pycnonotus barbatus Smith, 1858 of the family Pycnonotidae and Rhipidura fuscorufa Sclater, 1882 of the family Rhipiduridae. Two Capitonidae: P. chrysonocus and P. scolopaceus with relative frequencies of tufts of fruit in the order of $33.33 \%$ and $28.62 \%$ are the most active.

Table 1: Bird species and relative frequencies of visits in clutches of parasites

\begin{tabular}{|c|c|c|c|c|c|c|c|}
\hline Bird species & Family & Local name & $\begin{array}{l}\text { Total } \\
\text { ind }\end{array}$ & $\begin{array}{l}\mathrm{Nbv} \\
\mathrm{tfl}\end{array}$ & Frv & $\begin{array}{l}\mathrm{Nbv} \\
\mathrm{tfr}\end{array}$ & Frv \\
\hline Acanthiza nana & Psittacidae & Adondor & 5 & 7 & 1,85 & 0 & 0 \\
\hline Nectarinia coccinigaster & Nectariniidae & Adondôblè & 26 & 34 & 9 & 0 & 0 \\
\hline Nectarinia pulchella & Nectariniidae & Tintin 'blè & 95 & 158 & 41,80 & 0 & 0 \\
\hline Nectarinia senegalensis & Nectariniidae & Srika & 87 & 179 & 47,35 & 0 & 0 \\
\hline Pogoniulus atroflavus & Capittonidae & Agbitié kanliè & 75 & 0 & 0 & 52 & 17,51 \\
\hline Pogoniulus bilineatus & Capittonidae & Agbitiéblè & 28 & 0 & 0 & 20 & 6,73 \\
\hline Pogoniulus chrysonocus & Capittonidae & Agbitié valè & 77 & 0 & 0 & 99 & 33,33 \\
\hline Pogoniulus pusillus & Capittonidae & Agbitiépinplé & 11 & 0 & 0 & 15 & 5,05 \\
\hline Pogoniulus scolopaceus & Capittonidae & Agbitié ktokrô & 22 & 0 & 0 & 85 & 28,62 \\
\hline Pycnonotusbarbatus & Pycnonotidae & Pitchôkrô & 19 & 0 & 0 & 21 & 7,07 \\
\hline Rhipidura fuscorufa & Rhipiduridae & - & 3 & 0 & 0 & 3 & 1,01 \\
\hline Sylvia communis & Sylviidae & Kpaku/'lohle & 1 & 0 & 0 & 1 & 0,33 \\
\hline Streptopelia turtur & Colombidae & Aboubléblè & 1 & 0 & 0 & 1 & 0,33 \\
\hline Total & & & 450 & 378 & 100 & 297 & 100 \\
\hline
\end{tabular}




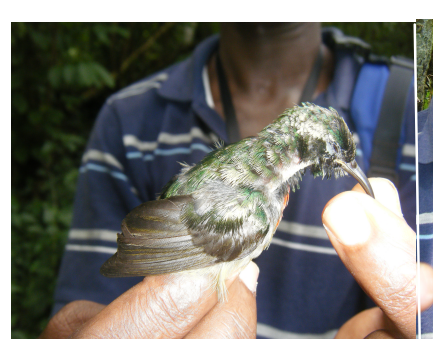

Figure 5: Nectarinia pulchella

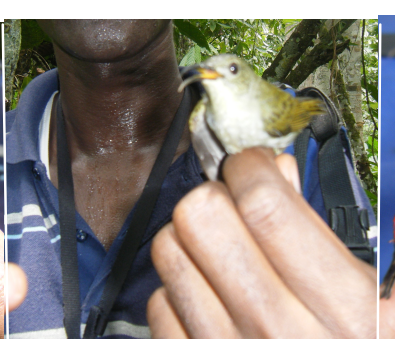

Figure 6: N. pulchella

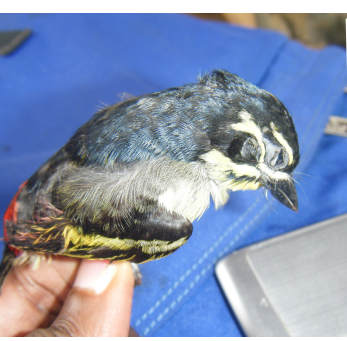

Figure 7: P. atroflavus

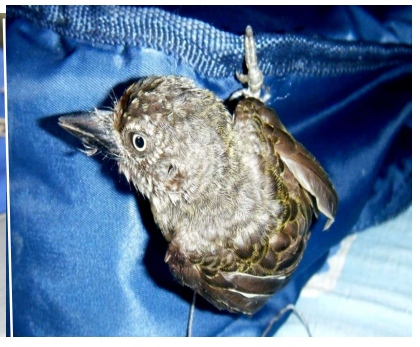

Figure 8: Pogoniulus scolopaceus

\subsection{Distribution of Loranthaceae on crops}

Table II shows the proportions of clumps of Loranthaceae per crop. Five (5) parasitic species invade cash crops. Among these species, P. capitata and T. bangwensis dominate all crops. However, T. bangwensis with $52.09 \%$ and $22.80 \%$ of total tufts respectively dominate cocoa and cocoa trees. As for P. capitata, it is more predominant on rubber trees $(51.76 \%)$.

Table 2: Proportion (\%) of Loranthaceae tufts per crop

\begin{tabular}{|c|c|c|c|c|c|c|c|}
\hline \multirow{3}{*}{$\begin{array}{l}\text { Parasitic } \\
\text { species }\end{array}$} & \multirow{3}{*}{$\begin{array}{l}\text { Total } \\
\text { number } \\
\text { of tufts }\end{array}$} & \multicolumn{4}{|c|}{ Annuity crops } & \multirow{2}{*}{\multicolumn{2}{|c|}{ Cocoa }} \\
\hline & & Cocoa & & Cocoa & & & \\
\hline & & $\begin{array}{l}\text { Number } \\
\text { tufts }\end{array}$ & $\begin{array}{c}\% \\
\text { presence }\end{array}$ & $\begin{array}{l}\text { Number } \\
\text { tufts }\end{array}$ & $\begin{array}{c}\% \\
\text { presence }\end{array}$ & $\begin{array}{l}\text { Number } \\
\text { tufts }\end{array}$ & $\begin{array}{c}\% \\
\text { presence }\end{array}$ \\
\hline $\begin{array}{l}\text { Globimetula } \\
\text { brunii }\end{array}$ & 1308 & 1308 & 100 & 0 & 0 & 0 & 0 \\
\hline $\begin{array}{l}\text { Phragmanthera } \\
\text { capitata }\end{array}$ & 6901 & 2941 & 42,62 & 740 & 10,72 & 3220 & 46,66 \\
\hline $\begin{array}{l}\text { Tapinanthus } \\
\text { bangwensis }\end{array}$ & 10549 & 5894 & 55,87 & 2220 & 21,05 & 2435 & 23,08 \\
\hline T. globiferus & 2207 & 2207 & 100 & 0 & 0 & 0 & 0 \\
\hline Total & 20965 & 12350 & 58,91 & 2960 & 14,12 & 5655 & 26,97 \\
\hline
\end{tabular}

Meaning of abbreviations: tfs - tufts

\subsection{Ecological habitat of Loranthaceae identified}


On the ecological level:

- G. braunii: heliophilus, inhabits aerated biotopes (upper branches) preferably;

- P. capitata: Present in many moist and aerated places (helio-sciaphile), living both outside and inside the host's crown;

- T. bangwensis: a heliophilus species present in several stations where it lives around the crown of its hosts;

- T. globiferus (A. Rich.) Tiegh: heliophilus parasitic plant that grows inside the crown of its hosts;

- T. sessilifolius var. glaber: heliophilus parasitic plant that prefers aerated biotopes. It attaches mostly to the edge of the host's crown.

\subsection{Degrees of infestation of crops with parasitic Loranthaceae}

The Figures 9 and 10 show infestation rates and intensities by crop. The analysis of variance performed indicates two statically different groups (a and b). The most infested group concerns cocoa and rubber trees with pairs of infestation values (rate and intensity) high respectively of (52.09\% and 4.75 tufts/plant) and (49.22\% and 3.25 tufts/plant). Coffee trees $(23.79 \%$ and 1.04 tufts/plant).

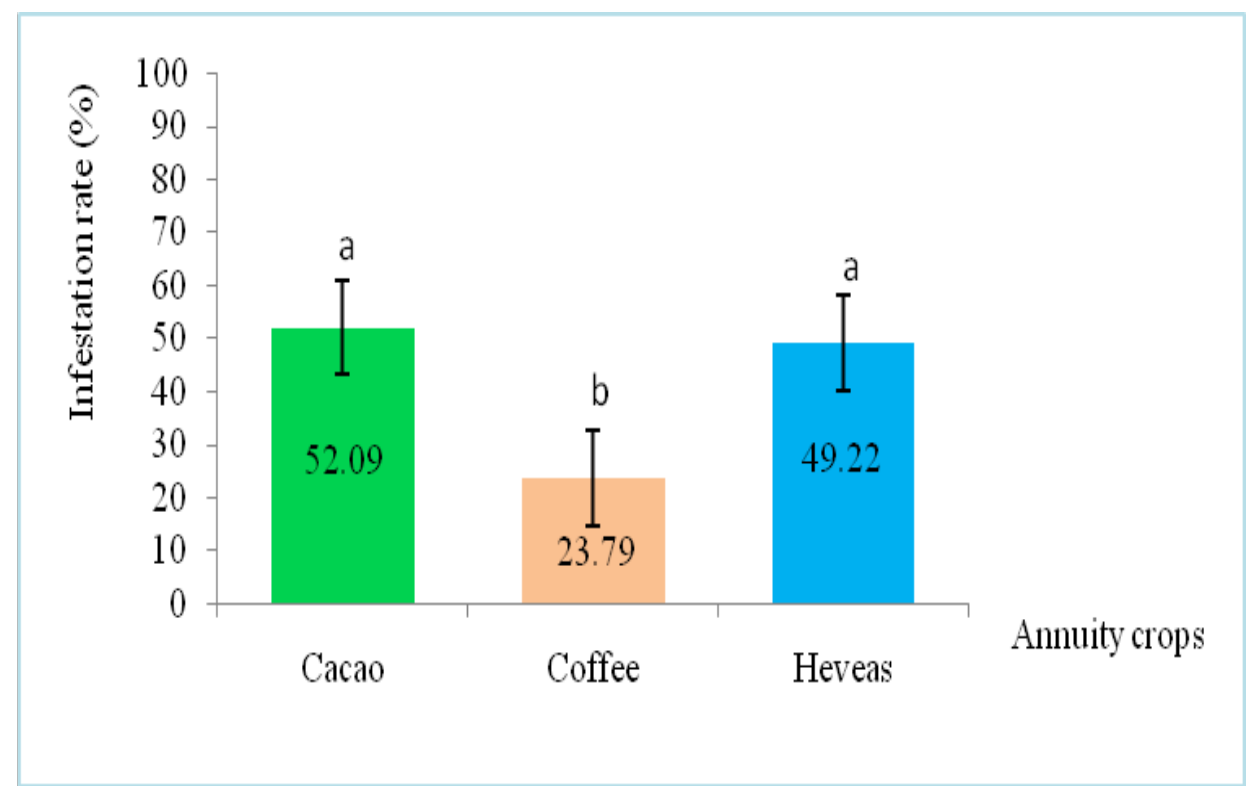

The letters $\mathrm{a}$ and $\mathrm{b}$ are statistically different (Newman-keuls test, $\mathrm{P}<0.05)$.

Figure 9: Rate of infestation of cash crops by Loranthaceae from plantations 


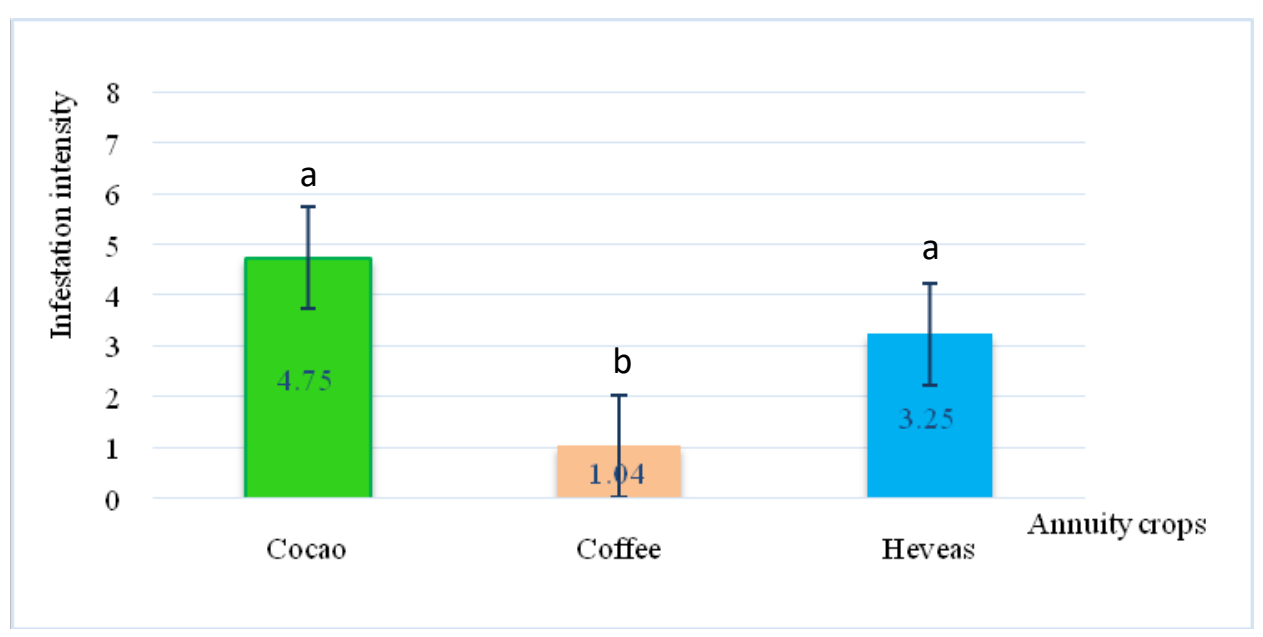

The letters $\mathrm{a}$ and $\mathrm{b}$ are statistically different (Newman-keuls test, $\mathrm{P}<0.05$ ).

Figure 10: Loranthaceae infestation intensities by annuity crop

It is also noted that cocoa trees have recorded a high infestation rate compared to that of rubber trees. However, the analysis of variance carried out did not show any significant difference between cocoa trees and rubber trees (Figures 9 and 10).

\section{DISCUSSION}

Four (4) species of Loranthaceae are identified on the cash crops of plantations in periurban areas of the department of Daloa, in central west Côte d'Ivoire. This result is similar to that of Mrankpa (2018) who inventoried these same 4 species on the site of the Jean Lorougnon Guédé University. On the other hand, this number is much lower than the seven (7) species inventoried by Amon (2014) in the South-East of the country. The presence of these species on cash crops in this part of the country would depend on their wide distribution in Côte d'Ivoire.

T. bangwensis and P. capitata, by their number of tufts on crops, are the most infesting parasites among the Loranthaceae species encountered in the plantations visited. Soro (2010) made the same observations in the West of the Côte d'Ivoire on the infesting character of T. bangwensis on the cocoa trees and P. capitata on the rubber trees.

Thirteen (13) bird species split into two groups visiting the flowering and fruiting tufts of Loranthaceae have been identified as agents involved in their expansion on crops. Four (4) of them including Nectarinia senegalensis, N. pulchella and N. coccinigaster have already been reported in their flowering tufts elsewhere in Africa (Dembelé et al., 1994; Boussim, 2002; Traoré et al., 2003). As for Acanthiza nana, it is newly identified in the tufts of Loranthaceae in Côte d'Ivoire.

Of the nine (9) short-beaked species visiting the Loranthaceae fruit tufts: Pogoniulus. atroflavus, P. bilineatus, P. chrysonocus, P. pusillus, P. scolopaceus, Pycnonotus barbatus, Rhipidura fuscorufa, Streptopelia turtur and Sylvia communis, only P. scolopaceus, Pycnonotus barbatus and Rhipidura fuscorufa were first reported as consumers berries and seed dispersers of 
Vol. 5, No. 04; 2020

ISSN: 2456-8643

Loranthaceae. In contrast, six (6) other species, including P. atroflavus, P. bilineatus, P. chrysonocus and P. pusillus were observed by Dembelé et al. (1994) in Mali and Boussim (2002) in Burkina Faso.

The largest attack of Loranthaceae on annuity crops was recorded in cocoa trees with an average infestation rate of $52.09 \%$. Coffee trees are the least attacked $(23.79 \%)$. These results corroborate those of Soro (2010) west of Côte d'Ivoire. The author justifies the heavy infestation of cocoa trees by the density of their foliage which would provide more security to the birds.

Of the four (4) species of Loranthaceae identified, T. bangwensis is predominant in terms of number of tufts on cocoa and coffee trees, just as $P$. capitata is on rubber trees. The uneven distribution of phytoparasites recorded is justified by the preference of certain species for a specific crop. This is the case with $P$. capitata, which infests rubber trees more (Gill and Onybe, 1990). These results confirm the work of and Guyot and Ntawanga Omanda (1998) in Gabon and that of Koffi (2004) in Côte d'Ivoire.

The most diverse genus in terms of species parasitizing cocoa and coffee trees is the genus Tapinanthus with two species: T. bangwensis and T. globiferus. This seems all the more worrying when you consider the enormous damage that the Tapinanthus genus causes to shea in Africa as pointed out by Traoré and $\mathrm{Da}$ (1996) and Soro (1999).

\section{CONCLUSION}

The Loranthaceae which infest the annuity crops of plantations in periurban areas of the department are four in number and include 3 genera. T. bangwensis is more distributed on cocoa and coffee trees, and P. capitata more infestant on rubber trees. Cocoa trees are the most infested and coffee trees the least infested.

Thirteen (13) species of birds divided into seven (7) genera and 7 families have been identified in the tufts of Loranthaceae as agents accountable for their dispersion. Two species of birds of the family Nectariniidae and three of the Capitonidae identified had a more active part in the flowering and fruiting tufts of phytoparasites.

\section{Conflict of interest}

The authors of this manuscript declare that there is no conflict of interest between them.

\section{Acknowledgements}

Village and peasant chiefdoms.

\section{REFERENCES}

Amon, A.D.E. (2014). Les Loranthaceae (guis), hémiparasites vasculaires des arbres et des arbustes des agroécosystèmes de la région du Sud-Comoé, en zone de forêt dense sempervirente de la Côte d'Ivoire. Mémoire de Thèse de l'Université Félix Houphouët-Boigny, option: Agroforesterie, 213p. 
Vol. 5, No. 04; 2020

ISSN: $2456-8643$

Borrow, N. \& Demey, R. (2008).Guide des Oiseaux de l'Afrique de l'Ouest. Delachaux \& Niestlé, 512p.

Boussim, I.J.(2002). Les Phanérogames parasites du Burkina Faso : inventaire, taxonomie, écologie et quelques aspects de leur biologie. Cas particulier des Loranthaceae parasites du karité, Thèse d'État, Université de Ouagadougou, 306p.

Eldin, M. (1971). Le climat in : Avenard, J. M. ; Girard, G. ; Siroulon, J. ; Ouchebeuf, P. ;Guillaumet, J.L. ; Adjanohoun, E. ; Perraud, A. ; (eds). Le Milieu naturel de Côte d'Ivoire, O.R.S.T.OM., Paris: $77-108$.

Dembelé, B. ; Raynal- Roques, A. ; Salle, G. et Tuquet, C. (1994). Plantes parasites des cultures et des semences forestières au Sahel, Institut du Sahel/C.T.A., 43p.

Gill, L. S. \& Onybe, H.I. (1990). Mistletoes on rubber-trees in Nigeria, Haustorium 23:1-2.

Guillaumet J.L. \& Adjanohoun E. (1971). La végétation. In : le milieu naturel de la Côte d'Ivoire. Mémoire ORSTOM, 50: 157-263

Guyot, J. \& Ntawanga Omanda, E. (1998). Note sur la sensibilité de six clones d'hévéa à Phragmenthera capitata. Phytopathologie, 6p.

Koffi, A.A. (2004). Evaluation de l'incidence des Loranthaceae sur la productivité de Hevea brasiliensis (Kunth) Müll. Arg. à Anguédédou (Sud de la Côte d'Ivoire). Mémoire de D.E.A. de Botanique, Université de Cocody-Abidjan: 52p.

Mrankpa, A.S. (2018). Diversité des Loranthaceae (guis) et des plantes hôtes du site de l'Université Jean Lorougnon Guédé, Côte d'Ivoire. Mémoire de Master de Bioressources et Agronomie, Option: Foresterie, Université Jean Lorougnon Guédé, Daloa, 60p.

Overton, J.M. (1994). Dispersal and infection Mistletoe met a population. Journal of Ecology, 82: 711-723.

Sallé, G. (2004). Les plantes parasites. http://www.futurasciencescom/comprendre/c/georges_salle.php [Consulté le 21/08/2019].

Serle, W.\& Morel, G.I.(1979). Les oiseaux de l'Ouest Africain. Lachaux Niestlé (éd.), NeuchâlParis.

Soro, D. (1999). Déparasitage par émondage et production en fruits du parc naturel à karité deTengrela, dans le Nord de la Côte d'Ivoire. Mémoire de DEA d'Écologie Tropicale, Option: Végétale, Université de Cocody, Abidjan, 84p.

Soro, D. (2006). Variabilité de quelques caractères morphologiques, production en fruits et moyen de lutte, par émondage, contre les Loranthaceae (Plantes vasculairesparasites) du karité : cas du parc naturel à karités de Tengrela dans, le Nord de la Côte d'Ivoire. Mémoire de Thèse Unique d'Écologie Végétale, option Agroforestérie, Université de Cocody, Abidjan, 139p. 
Soro, K. (2010). Les Loranthaceae (guis) des agroécosystèmes dans l'Ouest de la Côte d'Ivoire: flore, parasitisme et usages dans les Départements de Oumé, de Gagnoa et de Soubré. Mémoire de Thèse de 1'Université de Cocody-Abidjan, option Agroforesterie, 183p.

Traoré, D.; Da, K.P. et Soro, D. (2003). Lutte contre les plantes vasculaires parasites du karité, dans le Nord de la Côte d'Ivoire. Cas du parc naturel à karités de Tengrela, Universités de Cocody, U.F.R. Biosciences, Laboratoire de Botanique. Rapport de P.E.P/A.I.S.A. CI., 116p.. 